\title{
O espírito europeu (1946)
}

\section{György Lukács}

$\mathrm{Na}$ filosofia atualmente dominante, é comum tomar como ponto de partida a chamada "situação". Faremos o mesmo em nossas considerações, embora por "situação" não entendamos a situação individual do homem agindo isoladamente, mas a situação em que toda a humanidade se encontra hoje. Esta situação pode ser resumida da seguinte forma: o poderio militar do fascismo foi aniquilado pela guerra. No entanto, o desenvolvimento do período pós-guerra mostra que a aniquilação política, orgânica e, sobretudo, ideológica do fascismo é muito mais lenta e mais difícil de alcançar do que muitas pessoas imaginavam. Isso, do ponto de vista político, porque muitos estadistas, que enfaticamente se proclamam democratas, consideram os fascistas como uma reserva, poupam-nos e até os apoiam. E, por outro lado, a visão de mundo fascista está provando ser muito mais resistente do que muitas pessoas imaginaram após a aniquilação de Hitler.

Devo dizer que não estou entre aqueles que se surpreendem e se decepcionam com esse desenvolvimento. Mesmo antes da guerra, e durante ela, defendi constantemente a tese de que o fascismo não é de forma alguma, do ponto de vista histórico, uma manifestação mórbida isolada; de que ele não constitui uma erupção brusca da barbárie na civilização europeia. O fascismo como visão de mundo marca, antes, a culminação qualitativa de doutrinas irracionais no campo da teoria do conhecimento e de doutrinas aristocráticas de um ponto de vista social e moral,

\footnotetext{
" "O espírito europeu" foi o mote da primeira edição dos Encontros Internacionais de Genebra, ocorrida entre 2 e 14 de setembro de 1946. Além de Lukács, foram convidados a expor suas considerações sobre o tema Julien Benda, Georges Bernanos, Karl Jaspers, Stephen Spender, Jean Guéhenno, Francesco Flora, Denis de Rougemont e Jean-Rodolphe de Salis. Conferida originalmente em 9 de setembro de 1946, em alemão, a palestra (já em tradução francesa, feita por Renée Schidlof), foi publicada integralmente pela primeira vez no tomo I (1946) dos Textes des conférences et des entretiens organisés par les Rencontres Internationales de Genève. Les Éditions de la Baconnière, Neuchâtel, 1947, 364p. Collection: Histoire et société d'aujourd'hui. Para a presente tradução que inclui, além da conferência lukácsiana, seus pronunciamentos durante as sessões de discussão promovidas pela organização do evento, nos valemos da edição eletrônica dos anais supramencionados. Tradução de Carolina Peters (agradeço a Murilo Leite pelo auxílio no cotejo e revisão desta tradução). Revisão técnica da tradução de Vitor Bartoletti Sartori.
} 
doutrinas que, há muitas décadas, desempenham um papel proeminente tanto na ciência oficial quanto na não oficial, e no mundo da divulgação científica e pseudocientífica. Como estamos diante de um vínculo orgânico, é fácil para os adeptos espirituais do fascismo encontrar uma posição de recuo; eles podem repudiar Hitler e Rosenberg e, enquanto esperam uma oportunidade favorável para uma nova ofensiva, entrincheirar-se atrás da filosofia de Spengler ou Nietzsche. Eis um processo que pude observar pessoalmente, desde a sua origem, por ocasião das conferências que fiz durante a guerra com oficiais superiores alemães aprisionados.

Portanto, mesmo do ponto de vista da visão geral de mundo, a aniquilação da ideologia fascista não é de modo algum uma questão simples. Ao retirar do comércio os escritos de Mussolini, Hitler e Rosenberg, nada foi feito ainda. O que precisa ser aniquilado são as raízes espirituais e morais do fascismo. No entanto, isso não pode ser alcançado se não estiver claro quando e como surgiu a crise da qual o fascismo emergiu como uma forma peculiar, bárbara e desumana de seu desenvolvimento. Até agora, essa crise foi vista de diferentes maneiras, de diferentes pontos de vista. No entanto, as causas profundas de suas diferentes manifestações são idênticas em sua essência e, portanto, devem ser pensadas de forma idêntica.

Quando nos propomos a abranger, com o pensamento, essa crise em seu conjunto, nos deparamos com quatro grandes complexos: crise da democracia, crise da ideia de progresso, crise da crença na razão e crise do humanismo. Cada um desses complexos é o resultado do triunfo da grande Revolução Francesa. Todos os quatro alcançaram seu auge no período imperialista. Todos os quatro são qualitativamente acentuados durante o período entre as duas guerras mundiais, no período em que nasceu o fascismo. Pela conveniência da exposição, estudaremos esses quatro complexos separadamente, mas sem com isso perder de vista sua natureza comum. Porque a sua essência e, consequentemente, a forma de concebê-los constituem, de fato, uma unidade. Apenas a clareza da exposição obriga-nos a separá-los e mesmo assim, sem que o desejemos, os veremos se fundir.

Antes de passar propriamente à exposição, permitam-nos mais uma observação preliminar de ordem metodológica. Todos os argumentos usados contra a democracia e o progresso, contra a razão e o humanismo, não são meros sofismas vazios; eles emanam da própria essência social de nossa época. Como diz Marx, eles não passaram dos livros para a vida, mas da vida para os livros. Como resultado, todos esses 
desenvolvimentos refletem, embora desfigurados, problemas concretos, sofrimentos concretos, necessidades concretas. Por estarem assim comprometidos com o social, esses argumentos têm, portanto, uma espécie de justificativa intrínseca, e não podem ser simplesmente refutados pela prova de seu caráter contraditório ou mesmo de seu absurdo. Devemos, antes, mostrar que esse caráter contraditório, absurdo, tem sua origem em necessidades concretas, que ele contém os elementos de um problema justificado, mas colocado de forma distorcida e desfigurada, e que, por isso mesmo, esse problema, justificado do ponto de vista subjetivo, mas mal formulado do ponto de vista objetivo, só pode ser resolvido por uma resposta correta e adequada.

Por que foi precisamente a vitória da grande Revolução Francesa que causou essa crise? Porque são as condições históricas concretas dessa vitória, e seu paralelismo não fortuito com a revolução industrial inglesa, que asseguraram, em seu desenvolvimento antitético, o advento do capitalismo, base da sociedade burguesa moderna. Do ponto de vista da visão de mundo, a consequência desse fato é que a situação social assim criada comporta, ao mesmo tempo e inseparavelmente, uma realização e uma refutação das ideias da filosofia do lluminismo. Consideremos agora esses quatro complexos separadamente.

1. A crise social e intelectual da democracia tem sua origem no caráter antitético que apresentam a liberdade e a igualdade humanas, conforme sejam vistas no plano político ou no plano concreto. A famosa piada de Anatole France, de que a lei proíbe ricos e pobres de dormir sob as pontes com igual majestade, ${ }^{1}$ traduz esse complexo de contradições de uma forma que é clara e plástica. Alguns críticos clarividentes da sociedade, como Linguet, por exemplo, perceberam essas contradições antes mesmo da vitória da Revolução Francesa. Mas era necessário que a liberdade e a igualdade formais fossem realizadas na vida concreta para que seu caráter contraditório servisse como um centro de cristalização para todos os modos de agrupamento político e social do século XIX e, consequentemente, para as várias visões de mundo que se desenvolveram durante este período, a saber: tentativas, em primeiro lugar, de realizar concretamente a liberdade e a igualdade humanas, ou pelo menos tender para essa

\footnotetext{
${ }^{1}$ Lukács refere-se à célebre frase de Anatole France sobre "a majestosa igualdade das leis, que proíbe tanto o rico quanto o pobre de dormir sob as pontes, de mendigar nas ruas e de roubar pão" [Nota da Tradução].
} 
realização (jacobinos, democratas radicais, socialistas); ${ }^{2}$ em segundo lugar, os esforços para fixar juridicamente e idealizar pelo pensamento os resultados político-sociais da Revolução Francesa (liberalismo); e, em terceiro lugar, a tendência de considerar a desigualdade humana efetiva e sua ausência de liberdade como um "fato natural", uma "lei da natureza", ou um dado metafísico e, assim, tomar essas noções como ponto de partida de uma visão de mundo sui generis (várias tendências reacionárias, até o fascismo).

Esses grupos, que do ponto de vista tipológico esgotam as várias posições possíveis em relação aos principais problemas da crise da democracia moderna, estão na origem de todas as polêmicas, tão intimamente ligadas entre si apesar da sua diversidade, que opuseram, durante os séculos XIX e XX, as várias visões de mundo.

A ideia que liga os esforços das democracias revolucionárias radicais aos do socialismo é uma nova concepção de democracia, que pode ser resumida da seguinte forma: só se pode falar de democracia onde todas as formas concretas de dependência do homem em relação ao homem, a exploração e a opressão do homem pelo homem, a desigualdade social e a ausência de liberdade tenham desaparecido. É necessário, portanto, alcançar uma liberdade e uma igualdade que não ignorem as diferenças de situação econômica, nacionalidade, raça, sexo etc.

Só então a terceira grande etapa da igualdade humana seria realizada. Caracterizemos brevemente essas etapas: o Cristianismo proclamou a igualdade das almas humanas perante Deus; a Revolução Francesa, a do homem abstrato perante a lei; o socialismo realizará a igualdade humana concreta na vida real.

Do ponto de vista da visão de mundo, observemos ainda que todas essas tendências, apesar de sua diversidade, sempre consideraram e ainda consideram a igualdade como condição sine qua non do verdadeiro desenvolvimento da personalidade, e nunca como sua aniquilação. Do ponto de vista filosófico, a contribuição específica da nova interpretação e do desenvolvimento do materialismo na visão de mundo marxista é a seguinte: liberdade e igualdade não são ideias simples, mas formas de vida humana concretas, relações concretas entre os homens, entre eles e a sociedade e, por meio dela, entre eles e a natureza; consequentemente, sua

\footnotetext{
${ }^{2}$ Considerando que se trata da transcrição de uma exposição oral, não da letra lukácsiana, tomamos a liberdade de substituir os travessões por parênteses nos trechos em que Lukács apenas alude a exemplos, a fim de facilitar a leitura [N.T.].
} 
realização requer necessariamente que as condições sociais das relações humanas sejam modificadas.

Entre aqueles que foram, socialmente falando, os verdadeiros vitoriosos da Revolução Francesa, a ideia originária desta grande convulsão se cristaliza e desidrata cada vez mais, pelo próprio efeito de sua vitória. Quanto mais o liberalismo, considerado como a expressão espiritual e política dessas tendências sociais - em oposição à democracia radical e ao socialismo -, se encontra acuado na defensiva, do ponto de vista ideológico, mais os conceitos de liberdade e igualdade se tornam abstratos e formais. Certamente, esses conceitos já são pálidas ideias formais em Fichte e Kant. No entanto, com esses pensadores, a expressão filosófica das ideias de liberdade e igualdade se ligava a poderosas esperanças utópicas, cujo elemento patético as transportou - particularmente no que diz respeito ao jovem Fichte - muito além dos limites do formalismo. Do mesmo modo, a prática da Revolução Francesa raramente se eleva acima do conceito jurídico formal de liberdade e igualdade pensemos em Robespierre se posicionando contra as associações de trabalhadores mas aí, precisamente, é fácil ver como o utopismo plebeu dos sans-culottes ultrapassa os quadros estreitos da liberdade e igualdade formais, e tende a dar vida à liberdade e igualdade concretas.

O fundamento teórico - consciente ou inconsciente - de todas as concepções liberais é a economia clássica inglesa. A ideia de que uma liberdade de ação ilimitada do homo ceconomicus, no quadro da liberdade e da igualdade jurídicas formais, permite assegurar a todos os seres humanos, pelo funcionamento automático das forças econômicas, um estado social e cultural ideal, uma máxima felicidade e realização, está na base de todas as esperanças do liberalismo. Mas, desde o início do século XIX, essa concepção foi demolida pelo próprio desenvolvimento econômico, e essa contradição entre a concepção original da economia clássica inglesa e os fatos da vida econômica capitalista se reflete na derrota espiritual da economia clássica (discussão Ricardo-Sismondi, dissolução da escola ricardiana). Essa crise está levando a economia proletária ao seu ponto de maturidade. Além disso, a economia capitalista engendra - e isso mesmo antes do período imperialista - toda uma série de instituições - controle alfandegário, protecionismo, monopólios - que não só constituem uma refutação prática dos princípios da doutrina econômica clássica em sentido estrito, mas, ao mesmo tempo, derrubam todos os princípios fundamentais de uma visão de mundo segundo a qual uma renovação, ou tão simplesmente uma 
consolidação da humanidade, poderia ocorrer graças ao livre jogo das forças econômicas no quadro da liberdade e da igualdade formais. Tal situação engendra ou uma economia puramente empírica desprovida de qualquer fundamento ideológico, ou uma posição de defesa apologética cada vez mais exagerada. Defende-se uma liberdade e uma igualdade cada vez mais problemáticas, sem que uma crença fundada nos fatos permita esperar que o futuro possa algum dia corrigir as deficiências indiscutíveis do presente. Assim, a visão de mundo liberal se petrifica cada vez mais, porque a situação econômica e social a que corresponde torna-se cada vez mais irreal.

Esse entorpecimento também atua em uma parte importante do ser humano, na sociedade burguesa. A Revolução Francesa viveu em meio à tensão entre o cidadão e o burguês no seio de um povo livre. O grave e trágico problema humano da cidadania, que nasce dessa tensão, encontrou expressão na melhor poesia de todos os países do início do século XIX (Schiller, Hölderlin, Stendhal, Shelley). Mas o desenvolvimento que acabamos de esboçar e, sobretudo, a base econômica concreta desse desenvolvimento transformaram rapidamente o cidadão numa caricatura abstrata, da qual emerge de forma mais caricaturada os traços que, externamente, sobreviveram ao período iluminista e à Revolução Francesa, mas que, internamente, agora são destituídos de qualquer significação (Monsieur Homais, ${ }^{3}$ de Flaubert).

A democracia formal do liberalismo transforma o homem em uma pessoa privada. O desaparecimento do cidadão não corresponde apenas a um empobrecimento e a uma desespiritualização da vida pública, à qual voltaremos mais adiante, mas também a uma mutilação do homem enquanto indivíduo, enquanto personalidade. $O$ individualismo burguês moderno, tal como se desenvolveu sobre esta base - tanto faz se de acordo com ela, em um espírito de indiferença ou em um espírito de rejeição -, nada quer saber, que fique claro, dessa mutilação. Da afirmação estética da vida - no fim do século - ao entorpecimento sombrio de Heidegger em um nada destrutor, apenas o lado "homem privado" do ser humano - o lado "burguês" no sentido da Revolução Francesa - é reconhecido como essencial. Mas, como o homem, quer queira, quer não, e que se reconheça ou não, também pertence e participa da vida pública, todas as possibilidades e aptidões de sua personalidade que apenas encontram oportunidade de se desenvolver na vida pública são extirpadas, desse modo, de forma

\footnotetext{
3 Personagem do romance Madame Bovary, Monsieur Homais é um boticário, ou melhor, "farmacêutico", como ostenta na fachada de seu estabelecimento [N.T.].
} 
artificial e à força. Basta pensar nos Antigos para perceber até que ponto todas as formas de individualismo moderno são mutilações da personalidade humana.

Daí, aliás, uma falsa estruturação da economia privada do homem, do burguês. Quanto mais a economia capitalista se fetichiza, mais ela assume formas apologéticas e mais, ao mesmo tempo, a parte exploradora e parasitária do homo ceconomicus se identifica com sua personalidade. Parte-se da ideia - justificada em si mesma - de que para garantir o desenvolvimento da personalidade humana é indispensável reservar constantemente um terreno concreto para ela entre as coisas e as relações humanas. Mas essa ideia é então deformada a ponto de os meios para o homem explorá-lo acabarem assumindo $o$ valor de atributos fetichistas inseparáveis de sua personalidade; e é por isso que, nessa concepção de vida, a socialização da personalidade é logo considerada como sinônimo de sua aniquilação. O que não se leva em conta é que - do próprio ponto de vista do verdadeiro desenvolvimento da personalidade - o "terreno" em questão justamente apenas pode ser constituído por relações recíprocas, reais e concretas entre os homens e entre os homens e as coisas; e que, desde que existam essas relações e essa reciprocidade, não importa como as relações jurídicas de propriedade organizam dito "terreno"; pelo contrário, um direito de propriedade que não seja acompanhado por tais relações recíprocas - fato característico do capitalismo - paralisa o desenvolvimento da personalidade e a mutila, em vez de ser-lhe favorável. Foi isso que com clareza reconheceram estoicos e epicuristas. Não menos "fetichizada", aliás, [é] a concepção segundo a qual o desenvolvimento da personalidade em certos homens - os não-capitalistas - exigiria como estímulos a fome, a privação etc. É assim que o fetichismo desse período se transforma em um aristocratismo muitas vezes velado, mas em todo caso sempre transposto no plano objetivo, para o qual existem duas espécies distintas de homens, cujos respectivos desenvolvimentos requerem condições sociais opostas.

Assim, esse desenvolvimento leva ao mesmo tempo a uma deformação da personalidade, ao seu exagero fetichista e ao seu definhamento.

É impossível para nós descrever em detalhes aqui a crise da concepção liberal de mundo. Vamos simplesmente observar duas características. Em primeiro lugar, aquilo que se denomina problema da "constituição das massas", em que certos aspectos econômicos do desenvolvimento do capitalismo encontram-se fetichizados do ponto de vista da psicologia e da filosofia sociais; é necessário ver aí, no plano 
intelectual, um reflexo importante da crise de que falamos: o liberalismo se separa progressivamente da democracia, que cada vez mais se enfraquece e perde cada vez mais sua influência, exceto no interior do movimento socialista dos trabalhadores. Assim, se produz uma separação total entre o pensamento liberal e as massas; o medo e ao mesmo tempo o desprezo pelas massas emergem. Este desenvolvimento tem seu ponto de partida em Stuart Mill e atinge seu auge na psicologia social de Le Bon, na sociologia de Pareto, Michels etc. Nessa fase, ele se alia, nos sinceros representantes do pensamento liberal, a uma profunda resignação. O sociólogo mais importante desse período, Max Weber, lutou ao longo de toda sua vida pela democratização da Alemanha Guilhermina. Mas ele o fez com a ideia de que favoreceria o desenvolvimento de um sistema um pouco melhor do que o anterior do ponto de vista do "funcionamento técnico", e sem acreditar nem uma vírgula na possibilidade de uma conversão verdadeira do povo alemão, o que parecia lógico, dada a premissa de seu pensamento e a forma como julgava a situação.

Ao problema da "constituição das massas" se relaciona intimamente o da "elite" e da "escolha dos líderes". Também aqui há razão em si para colocar tal problema, e nem mesmo é incorreto constatar que a elite se torne amplamente independente das massas que supostamente representa. O problema só se distorce quando é generalizado, extrapolando o quadro da história, perdendo assim de vista o fato de que se trata apenas de um fato social particular em uma determinada fase do desenvolvimento do capitalismo. A constatação, exata quanto a esta fase, denuncia uma das fragilidades centrais da democracia burguesa formal. Do ponto de vista formal, as massas aparecem - no exercício do direito de voto - como senhoras absolutas, irrevogáveis; mas, na verdade, elas são totalmente impotentes e devem permanecer assim, pela vontade daqueles que manipulam os cordéis da marionete. Evoquemos poucos fatos: o enorme custo do aparelho eleitoral, os jornais destinados às massas etc. bastam para trazer isso à luz; em tal organização econômica, o poder total está necessariamente concentrado em poucas mãos. A imprensa, a literatura, o cinema etc. assim dirigidos tendem a despolitizar o espírito das massas, pois somente dessa forma a propaganda eleitoral poderá facilmente afetá-las. Resumindo: a chamada nova elite é, na realidade, escolhida por um pequeno número de personagens anônimos, dentre os quais a maioria permanece oculta, em segundo plano; parcialmente, essa elite escolhe a si mesma; mas em todo caso, suas insuficiências, sua irresponsabilidade e sua corrupção serão atribuídas à democracia, às massas, porque, 
formalmente, foram elas que a elegeram. Em terreno tão duvidoso, só pode se desenvolver a incoerência ou, melhor, a hipocrisia de pensamento, e a resignação profunda continua sendo o único resultado possível para o pensamento subjetivamente honesto.

A nova ideologia, abertamente antidemocrática, nasce dessa crise. 0 anticapitalismo romântico que se desenvolveu em rebelião contra a cultura capitalista no início do século [XIX] exibe primeiramente traços democráticos, que logo perde, porém, à medida que a crise se desenvolve (mudança de atitude de Carlyle após 1848). A oposição romântica da segunda metade do século coloca abertamente a desigualdade e a ausência de liberdade na base de uma sociedade "saudável". Essa concepção tem muitos pontos em comum com a ideologia da Restauração após a Revolução Francesa, mas de forma alguma traduz uma tentativa de restauração pura e simples do sistema feudal absolutista que então havia sido aniquilado; na verdade, é um novo produto da crise moderna da democracia. Pode-se considerar o pensamento de Nietzsche como o fenômeno mais importante que marca a passagem para essas novas concepções.

É fácil compreender por que a ideologia antidemocrática e não igualitária encontra sua fundamentação científica acima de tudo na biologia. Com efeito, só a demonstração da existência de uma desigualdade biológica irremediável entre os seres humanos pode fornecer-lhe a aparência de uma base racional. Na verdade, essa tal biologia não é de forma alguma uma ciência, é um mito. Já podemos ver isso claramente em Nietzsche; sua "raça dos senhores" tem, na realidade, apenas um fundamento romântico-moral, e a biologia figura aí simplesmente como ornamentação mística.

Outro mito biológico grosseiro se desenvolve paralelamente: o da teoria das raças. Aqui, novamente, não se trata de uma teoria baseada nos resultados das ciências naturais, mas da necessidade metodológica, nascida no plano político-social, de demonstrar a existência de uma desigualdade radical entre os indivíduos dentro de um mesmo povo, ou de vários povos entre si. Tal teoria constitui a negação brutal de uma verdade antiga: aquela que afirmava que a diversidade das personalidades, as próprias diferenças individuais se conciliam perfeitamente com a igualdade de direitos, tanto entre as pessoas como entre os povos, e que essa diversidade apenas se torna tolerável através da igualdade das condições de desenvolvimento econômico e social. 
A teoria das raças, a doutrina radical da desigualdade, é sistematicamente desenvolvida pela primeira vez em Gobineau, e não é por acaso que seus primeiros leitores e adeptos foram recrutados entre os proprietários de escravos americanos, conforme aparece na correspondência [com] Tocqueville. Em efeito, apenas posta de forma tão radical uma diversidade qualitativa entre os seres humanos pode servir de fundamento para uma moral, uma sociologia, uma filosofia da história da qual se segue que certas raças não pertencem à humanidade e justificar o total confisco dos direitos humanos dessas raças.

Mesmo dentro desse campo, ocorreram violentas lutas de tendência, lutas nas quais o mito biológico grosseiro prevaleceria cada vez mais claramente, e a psicologia moral, por sua vez reduzida também aos mitos, seria empurrada cada vez mais para o segundo plano. Mas o fato de que a orientação de Chamberlain-Rosenberg dominaria a orientação nietzscheana não deve nos fazer perder de vista o fato de que, quando se trata do desfecho da crise da democracia, essas duas orientações convergem.

Assim, se desenvolveu no entre guerras uma situação paradoxal na qual o mundo civilizado em sua quase totalidade era governado de acordo com os princípios democráticos, enquanto a democracia havia perdido todo o poder e todos os seus defensores. A República de Weimar foi uma democracia sem democratas e, como seu aparelho governamental atuou apenas em benefício de uma pequena minoria anônima, gerou um desapontamento geral e profundo entre as massas alemãs com relação à democracia. O poder de persuasão da verdadeira convicção faltava a seus melhores defensores, como Max Weber. E o que é mais grave, os únicos possíveis defensores ativos da democracia, os trabalhadores revolucionários, foram assim levados a se tornarem oponentes cada vez mais ferrenhos da democracia. A opinião cada vez mais difundida naquela época de que o mundo deveria escolher entre o fascismo e o bolchevismo confundiu os oponentes do fascismo, e tornou impossível construir uma frente antifascista naquela altura. Foi somente por meio desse caos ideológico que o fascismo pôde aparecer tanto para as massas desamparadas quanto para uma elite intelectual desesperada como uma solução para a crise da democracia.

É assim que a estratégia de Hitler pôde seguir de vitória em vitória até 1941. Somente a aliança de 1941, a aliança entre democracia e socialismo, pôde levar a um ponto de inflexão na história, fazendo surgir a possibilidade de salvar a civilização. 
2. Todos esses problemas nos levam ao segundo complexo crítico: a crise da ideia de progresso. Do ponto de vista filosófico, a noção de progresso pressupõe a descoberta, no seio da sociedade, de tendências constantes, senão uniformes, para a melhoria dos valores humanos, descoberta que permite assim fundamentar essa noção de progresso em uma realidade concreta. Tal concepção filosófica implica tanto a aspiração a um estado ideal - em uma ideia de perfectibilidade indefinida, como Kant a concebe - quanto a possibilidade concreta de modificar qualitativamente a situação presente, possibilidade que garante o florescimento das forças "naturais" da humanidade (capitalismo na economia clássica, objetivos propostos pela filosofia do Iluminismo, objetivos da Revolução Francesa etc.). Ora, na crise cujas características acabamos de delinear, essa crença na realização concreta do progresso desapareceu. Portanto, se a noção de perfectibilidade indefinida permanece isolada, como é o caso do neokantismo liberal, toda conexão com a realidade social concreta é perdida, tudo se torna abstrato, desprovido de força e poder de persuasão. No entanto, tal desenvolvimento é socialmente necessário. Sob uma forma acadêmica, essa noção ainda é encontrada entre os neokantianos. Mas tal concepção, na qual o descompasso entre o ideal e a realidade aparece como inevitável e radicalmente intransponível, logo conduz a um profundo pessimismo cultural entre a elite intelectual. Da Impotência da razão, de Scheler, a Valéry, vê-se aparecer a concepção de uma resistência heroica e solitária, de uma morte heroica por uma causa perdida; defende-se ideais que sabemos muito bem que não estão vinculados a nenhuma realidade social concreta nem poderiam estar. A evolução cultural da elite espiritual é perseguida com resignação aristocrática, distante da realidade hostil às ideias. A colocação em prática dos ideais deve ser transposta para o plano interior. Em seu desenvolvimento, o homem isolado ainda pode lutar pelo progresso, a sociedade não pode.

Relacionado a essa evolução, está o conflito entre cultura e civilização, que exerceu enorme influência nas últimas décadas. Em termos gerais, esse conflito repousa na ideia de que o progresso é possível no plano exterior, da civilização, e, em particular, da civilização técnica, mas não no plano verdadeiramente fundamental, da cultura. Aqui, novamente, trata-se de uma resposta falsa dada a uma questão em si mesma perfeitamente fundamentada. É com razão que a elite intelectual protestou contra o fato de que o desenvolvimento da cultura fosse tratado segundo o esquema de um puro e simples progresso técnico. Para o dialético, o próprio princípio do desenvolvimento da cultura reside em sua não uniformidade. Schiller já sabia que, no 
campo da arte, uma evolução, um progresso pode perfeitamente ocorrer sem que se devam considerar as criações futuras como superiores às do passado. É só porque a elite intelectual se encontra perdida na sociedade moderna, porque é "organicamente" incapaz de descobrir os caminhos e os meios do progresso real, que o conflito entre cultura e civilização pôde nascer. E seria oportuno examinar em profundidade a relação entre esses dois fenômenos, em cuja origem também aparece, é claro, certo estacionamento dos ideais liberais.

Assim, aparece relativamente cedo a negação do progresso histórico. Ela é mais radical em Schopenhauer, mas também se encontra, definitivamente, em Kierkegaard e na escola histórica romântica alemã, em Ranke e em seus sucessores. Nietzsche tenta fundar sobre essa base uma utopia reacionária. Mas, de fato, por um lado, sua verdadeira concepção da história é muito próxima à de Schopenhauer: a história nos oferece o espetáculo de uma corrupção constante, de um declínio inevitável, e seus raros pontos de inflexão favoráveis são milagres. $\mathrm{E}$, por outro lado, sua doutrina do eterno retorno das coisas é uma nova negação de todo desenvolvimento histórico, de todo progresso. Lá onde o progresso, do modo como o compreende, deve ser constatado, ele se perde no puro mito.

Uma relação muito interessante pode ser observada aqui: o pessimismo social emerge de uma concepção estática da história; a doutrina antidemocrática está estreitamente ligada à negação do progresso; tudo o que a história pode eventualmente sustentar de bom pertence ao passado; o próprio processo histórico só pode consistir em um lapso; o melhor que se pode fazer é voltar a um estado anterior. Mas esse resultado não pode ser obtido organicamente, por meio do desenvolvimento histórico; constitui um brusco salto qualitativo.

É essa última ideia que domina, em particular, a teoria das raças. A Idade Média do anticapitalismo romântico torna-se aqui o estado original da raça pura. $O$ desenvolvimento histórico se manifesta apenas na miscigenação das raças e, consequentemente, na sua corrupção. Daí o pessimismo de um Gobineau. A ideologia fascista é construída sobre essas bases, nega radicalmente qualquer ideia de progresso e assenta sobre um "milagre" - termo usado por Hitler para designar sua própria missão - a perspectiva de um restabelecimento do estado original.

Desse modo, por um lado, a noção de elite, a concepção aristocrática, torna-se acessível também para as grandes massas porque é aplicável a povos inteiros; por 
outro lado, essa concepção adquire uma base totalmente rígida e totalmente arbitrária. O racismo radical desenvolveu-se por muito tempo dentro de pequenas seitas; no entanto, uma vez que essas seitas viviam em um ambiente por si só aristocrático, onde a noção de elite repousava, sobretudo, em concepções moral-sociais, psíquicas ou espirituais, mas sempre se resumia em última instância a um mito racista (Nietzsche e Spengler), sua influência se expandiu cada vez mais. Claro, foram as condições sociais do período preparatório para a Segunda Guerra Mundial que levaram à vitória do movimento fascista entre as massas.

É necessário destacar, aqui, uma convergência entre a noção de democracia ou a concepção antidemocrática, de um lado, e o que se convencionou chamar de "posições extremas" em matéria filosófica, de outro, convergência que de nenhuma maneira é uma construção abstrata pura, uma "tipologia" - sempre mais ou menos arbitrária -, tal como a encontramos nas ciências do espírito. Trata-se, antes, de mostrar como se comportam os pensadores diante de certas tendências concretas de seu meio social, como interpretam essas tendências, que posição - positiva ou negativa - eles assumem em relação a elas, se as negam ou se as reconhecem etc. $O$ vínculo entre, por um lado, progresso e democracia e, por outro, negação do progresso e uma concepção aristocrática é, portanto, um fato da vida concreta.

Não é de modo algum por acaso que o conceito de pessimismo surge aqui. Aqui, novamente, pode-se destacar uma conexão importante - fundamentada no desenvolvimento social concreto. Não é de modo algum por acaso que o progresso, o otimismo e a democracia, por um lado, a oposição ao progresso, o pessimismo e o ponto de vista aristocrático, por outro, caminham juntos. Pois, embora os fatos naturais pareçam desempenhar um grande papel na controvérsia entre o otimismo e o pessimismo, ainda assim é o ponto de vista social que tem a última palavra, e os fatos naturais apenas Ihes fornecem justificativas. O fato de que todo o planeta e, com ele, toda a cultura humana um dia desaparecerão não pode perturbar um democrata otimista e, por outro lado, Chamberlain e Nietzsche mostraram como é possível usar o darwinismo para fins de uma filosofia antievolucionista.

O crescente poder do pessimismo dos nossos dias evidencia particularmente bem as raízes sociais dessa concepção, embora se apresente essencialmente como pessimismo cultural, como uma negação do progresso no que diz respeito aos problemas humanos fundamentais. A situação da elite intelectual de nosso tempo, do 
modo como acabamos de descrevê-la, está intimamente relacionada ao fato de que o pessimismo se apresenta cada vez mais como uma atitude distinta, em oposição ao robusto otimismo plebeu; aparece como a única atitude espiritual autêntica possível, moralmente superior ao otimismo. Aqui, novamente, trata-se de um ponto de vista parcialmente justificado: em um ambiente fundado na apologia da vida capitalista, onde toda feiura, baixeza, desumanidade devem ser parcialmente negadas, parcialmente idealizadas, em um ambiente onde reina uma concepção vulgar de progresso, identificando o desenvolvimento deste tipo de economia e sua civilização técnica como uma marcha ascendente - sem levar em conta os efeitos destrutivos dessa evolução nos planos humano e cultural -, o ceticismo e mesmo o pessimismo podem muito bem ser mantidos em um nível intelectual e moral superior ao de seus adversários. Mas uma reversão de valores ainda é iminente. Ocorre assim que esse pessimismo se transforma em uma concepção aristocrática que se satisfaz por si mesma, e logo leva a uma aliança com as forças da reação. $O$ anti-historicismo e o pessimismo metafísico de Schopenhauer pretendiam se elevar acima da mesquinhez da vida social e política. Mas, na realidade, eles não estavam fazendo outra coisa, e isso no próprio Schopenhauer, a não ser apoiar o Terror Branco de 1848 e do pós1848. E o progresso dessas tendências aristocráticas pessimistas, depois de Schopenhauer, apenas reforça esse caráter decadente e reacionário. Não é à toa que Thomas Mann, para caracterizar nosso tempo, fale da força de atração da doença, do definhamento e da morte.

Todas essas tendências são levadas ao extremo dentro do fascismo, pois, como acabamos de ver, a característica dessas teorias das raças é um pessimismo e um aristocratismo absolutos. O "pessimismo heroico" do fascista é uma filosofia fundada no mais extremo desprezo pelo homem, na exploração sem escrúpulos do profundo desespero das grandes massas e de uma elite intelectual desorientada. Os campos de extermínio de Auschwitz ou Majdaneck são a consequência imediata da política imperialista do fascismo. Mas este sistema político e suas manifestações nunca teriam conseguido se desenvolver sem esse aristocratismo que considera todo ser de outra raça como não-humano, sem uma concepção universal do desespero, sem a ausência de qualquer visão social e histórica, tudo o que coloca uma nação inteira e seu destino na situação de um aventureiro à beira do abismo. 
3. Já estamos tocando mais de perto os problemas propriamente filosóficos, que são o assunto deste estudo. As seguintes considerações nos levarão à questão central: negação ou afirmação da razão. Considerar a posição da filosofia em relação à razão como um problema imanente à filosofia - no domínio da teoria do conhecimento, da fenomenologia ou da ontologia - é obra de um falso academicismo. Todas essas disciplinas são apenas aspectos da filosofia geral, cujos fundamentos devem ser buscados no próprio ser, como os gregos já haviam visto, assim como Fichte, para não falar dos materialistas. Para qualquer problema relevante da teoria do conhecimento ou de algum outro ramo da filosofia, os modos de colocá-lo e resolvê-lo dependem da maneira como o filósofo concebe a relação entre o ser e a razão e diferem conforme, para ele, o núcleo da existência, a essência do ser, seja de natureza racional ou irracional.

É impossível abordar aqui, mesmo de passagem, o problema filosófico do irracionalismo. Contentemo-nos em indicar a sua ligação com o nosso problema, com o dilema aristocrático-democrático. Novamente aqui, a coordenação é claramente visível. Não, é claro, no sentido simplista em que se perguntaria se, de um ponto de vista político, certo pensador tem opiniões de direita ou de esquerda. A esse respeito, há exceções frequentes: por exemplo, Sorel. Mas, no que diz respeito à visão geral de mundo, a ligação é inequívoca: o ponto de vista antiprogressista está quase sempre estreitamente relacionado ao irracionalismo e à tão peculiar noção de "nova elite". As tendências fundamentais de um Sorel correspondiam, certamente, a uma mentalidade socialista; mas, certamente, não a uma mentalidade democrática. A ruptura, tão carregada de consequências, entre socialismo e democracia também se manifesta em sua filosofia.

De acordo com sua gênese histórica, a ideologia antirracionalista se originou em oposição à Revolução Francesa e, por esta razão, se opõe fortemente ao conceito de progresso, à ideia de que as coisas do passado devem necessariamente ser destruídas por coisas novas. Constitui, portanto, antecipadamente uma defesa da velha sociedade aristocrática, e não apenas no plano político. Sua visão geral de mundo é dirigida contra o racionalismo da filosofia do lluminismo, e pretende defender instituições etc. pela simples razão de existirem, mantendo as tradições apenas porque parecem estar vivas, tudo sem se preocupar se são ou não racionais. É, portanto, a rejeição da racionalidade como critério. $\mathrm{A}$ independência assim posta em relação à razão torna-se uma concepção positiva: porque essas instituições, essas tradições etc. representam 
algo superior a toda racionalidade, vemos nelas o núcleo suprarracional, irracional, de toda realidade. O fato de que um Burke, um de Maistre ou um Haller pareceriam singularmente racionais diante dos irracionalistas de hoje apenas destaca a profundidade e a amplitude do desenvolvimento assumido por essa concepção de mundo. A relação entre o irracionalismo e a visão de mundo aristocrática não determina apenas a gênese dessa concepção, mas também sua própria estrutura filosófica. Pensemos na controvérsia entre Schelling e Hegel a respeito da intuição intelectual. Aqui, a oposição é elevada de forma duradoura ao nível filosófico e, ao mesmo tempo, o caráter, respectivamente, aristocrático e democrático dos dois pontos de vista encontra-se claramente expresso. Schelling pensa que a intuição intelectual, ou seja, o órgão que nos permite acessar a realidade em si, requer um dom genial, que não pode ser adquirido pelo estudo. Essa ideia encontra seu desenvolvimento através de Schopenhauer, Nietzsche, Bergson e da escola de George, até o irracionalismo contemporâneo. O importante não é distinguir entre os requisitos de "gênio" estético, moral, filosófico, psicológico etc. O que importa é o princípio aristocrático que, desde Chamberlain, também se apresenta como um princípio racista.

Em contrapartida, Hegel defende o ponto de vista de que todo homem tem os meios para acessar uma concepção filosófica da realidade. Isso de forma alguma significa que Hegel acredite que o conhecimento filosófico seja acessível sem mais a toda inteligência humana saudável, e que ele considere supérfluo o trabalho técnico preparatório para a filosofia. Seu ponto de vista implica apenas que, em princípio, esse caminho está aberto a qualquer homem normal. A comparação que ele faz a esse respeito é bastante significativa: qualquer soldado de Napoleão poderia se tornar um marechal, mas, é claro, nem todos se tornariam; o mesmo se aplica ao acesso dos homens ao conhecimento filosófico. A Fenomenologia do Espírito de Hegel se dirige contra Schelling já pelo simples fato de que ela opõe ao "salto" irracional e genial da intuição intelectual um caminho racional - tanto individual quanto coletivo, tanto antropológico quanto histórico e social - para a compreensão do mundo.

Claro, a importância da mudança de ponto de vista que ocorreu aqui não deve ser minimizada: a razão hegeliana não é idêntica à dos filósofos do lluminismo. Entre elas está a Revolução Francesa e a crise da humanidade provocada por sua vitória, crise cujo contragolpe nós acabamos de estudar na crise do pensamento democrático e da ideia de progresso. Em Hegel, a mudança de ponto de vista marca todos os problemas, bem como a própria estrutura de sua visão de mundo. Aqui, novamente, 
podemos apenas esboçar o fenômeno em linhas gerais. Acabamos de mostrar as relações entre Hegel e a filosofia irracionalista de sua época; também sabemos qual foi a atitude de Hegel em relação à Restauração e ao Romantismo. Em nosso tempo, tentou-se muitas vezes negar ou atenuar a sua oposição claramente manifesta em relação a essas tendências, embora baste reler as passagens relativas a Haller ou a Savigny da Filosofia do direito para ver claramente qual era a sua posição. Durante a Revolução Francesa, a razão, como também diz claramente Hegel, tornou-se senhora da sociedade e da história. O reino da razão foi, portanto, realizado. Mas como se apresenta essa realização? Como Engels muito acertadamente mostra, esse reinado se apresenta, ao mesmo tempo, como o da burguesia. Acabamos de revisar brevemente as contradições que se manifestaram a esse respeito em todos os âmbitos da vida.

Diante da contradição inerente a toda realidade histórica-social, a filosofia pode escolher entre três possibilidades: primeiramente, estreitar e empobrecer a noção de razão, para que o domínio da burguesia possa continuar a parecer o da razão; em segundo lugar, considerar a realidade como irracional; e deixaremos de lado, aqui novamente, as múltiplas variações possíveis dentro desses dois pontos de vista.

Hegel, por sua vez, faz aparecer uma terceira possibilidade: enquanto na presença das contradições de que falamos, um desses dois pontos de vista se transforma na negação da razão e o outro procura simplesmente escapar das contradições, Hegel resolutamente instala essas contradições no centro da própria filosofia, da lógica, bem como da ontologia, e de cada parte concreta da filosofia, seja ela a filosofia social ou a filosofia da história. Todos os elementos da realidade que tomados isoladamente e como absolutos -, enquanto fatos definitivos que não podem ser mudados, servem de base para o irracionalismo aparecem, em Hegel, como simples elementos da nova razão, como problemas que se resolvem dialeticamente. Todas as contradições que a filosofia pré-hegeliana considerou como conflitos entre a razão e a realidade aparecem agora como simples oposições dialéticas da inteligência que conduzem ao novo racionalismo.

Desse modo, duas linhas filosóficas encontram seu ponto culminante em Hegel: em primeiro lugar, a antiga filosofia dos contrários, cuja descoberta remonta aos eleatas e a Heráclito, mas na qual Hegel sistematicamente introduz a contradição como fundamento de toda filosofia; em segundo lugar, a filosofia racionalista moderna, tal qual remonta a Descartes, mas levando em conta a convulsão mundial devida à 
Revolução Francesa. Uma exposição detalhada é aqui, obviamente, impossível. Sublinhemos apenas, para melhor situar o problema, dois pontos característicos. Por um lado, a razão na história. O anti-historicismo dos filósofos do lluminismo, tão frequentemente aludido, é certamente uma lenda reacionária. Mas é verdade que, segundo a concepção desses filósofos, a razão única e imutável se afirma através das vicissitudes da história. Ao contrário, Hegel mostra a evolução, a realização, a tomada de consciência e a afirmação da razão na história, pela história. E, por outro lado, as contradições da vida, elevadas até ao nível da tragédia, aparecem como veículos e manifestações supremos da própria razão. Isso é particularmente visível na relação entre o indivíduo e o gênero. Mas os povos e as nações também são indivíduos desse ponto de vista. A tragédia aparece como a mais elevada forma de realização concreta que a razão pode alcançar. Essa é a ideia comum ao Fausto, de Goethe, e à Fenomenologia do Espírito, de Hegel.

Assim, a doutrina de Hegel resolve e elimina da maneira mais adequada a crise gerada pela Revolução Francesa. No entanto, e por melhor que ela seja, essa filosofia é apenas uma conquista relativa, metodológica. $O$ conceito histórico de razão antitética foi descoberto, mas do ponto de vista do próprio Hegel, sua plena realização histórica era impossível. É a liberdade que, com seu novo sentido, deve se tornar o conceito central do desenvolvimento interno, em si mesmo antitético, da razão, mas, do ponto de vista concreto, a filosofia hegeliana da liberdade marca, em decorrência das condições gerais desfavoráveis desse período (particularmente na Alemanha), um retrocesso mesmo em comparação com a Revolução Francesa. É por isso que uma névoa reluzente envolve a figura de Hegel. Alguns o chamam de filósofo do prussianismo reacionário, enquanto Herzen vê seu método como a álgebra da revolução.

Como seus alunos e seus sucessores burgueses não seguem a linha de Herzen, as novidades mais preciosas da dialética hegeliana se perdem cada vez mais; as inovações acadêmicas permanecem ineficazes precisamente no que diz respeito à questão principal. Apenas em Marx veremos os resultados e as experiências concretas desse período incorporados ao método filosófico. Em Marx, a razão hegeliana desce radicalmente sobre a terra. A conquista da liberdade e da igualdade torna-se a demanda por liberdade e igualdade concretas para os homens realmente existentes em uma sociedade concreta. É somente a partir de Marx e de seus grandes sucessores que o gênero concreto, despertando por seu desenvolvimento antitético e, por meio 
das antíteses, para a autoconsciência e a atividade espontânea, torna-se o verdadeiro sujeito da história. Foi Marx quem primeiro destacou o verdadeiro desenvolvimento do homem - e não esse sentimento distorcido pelo capitalismo que o torna um átomo no mundo fetichizado - em suas relações concretas e antitéticas com os outros homens. As relações entre os homens aparecem agora como o fundamento da estrutura e do dinamismo do progresso, como os órgãos vivos pelos quais a razão se realiza na história.

Essa grande filosofia até agora permaneceu quase completamente ineficaz no mundo burguês; era preciso, portanto, esquecer ou disfarçar a dialética. No entanto, o curso das coisas não pode ser interrompido por este silêncio e esta mutilação: continuamente, novos e cada vez mais importantes problemas dialéticos se apresentam - problemas que, como resultado da evolução filosófica que acabamos de esboçar, aparecem a cada vez como "dados insolúveis" do irracionalismo. Assim, estreitadas e distorcidas, as perguntas necessariamente recebem respostas falsas e inadequadas, sem relação com problemas humanos concretos.

4. Aqui, chegamos à crise do humanismo. Não há necessidade de longos discursos para destacar o fato de que esta crise existe. Basta lembrar que o fascismo reinou por doze anos na Alemanha. Mas em que consiste essa crise do humanismo? Originalmente, e por sua essência, o humanismo é um conhecimento do homem, com vistas à defesa de sua dignidade e de seus direitos. É por isso que o humanismo foi combativo e até agressivo desde a Renascença e através do século XVIII até o apogeu da Revolução Francesa. A crise que acabamos de analisar manifesta-se da seguinte forma, no que diz respeito ao humanismo: quanto mais estreitamente se unem às filosofias antidemocráticas e antiprogressistas e, em particular, às filosofias racistas, mais as diferentes ciências se desenvolvem em direções anti-humanistas. O humanismo deixa de se fundamentar nas ciências humanas concretas. E, por sua vez, a defesa da dignidade e dos direitos humanos se reduz cada vez mais a uma simples atitude defensiva, ideologicamente enrijecida em abstrações, e leva a uma passividade cada vez maior e, pela perda do contato com qualquer realidade social concreta, a um utopismo pálido. As causas decisivas desta crise emergem claramente da nossa análise anterior: o indivíduo isolado, que fundamenta os seus postulados de vida sobre esse isolamento, e que acredita ser uma pessoa privada em face de uma sociedade estranha, 
morta e desumana, só pode procurar, sobre esta base, meios pacifistas de proteger seu retiro.

Esse empobrecimento do humanismo se manifesta claramente em sua atitude a respeito do próprio passado e de sua maior conquista prática, a Revolução Francesa. Grandes escritores humanistas, como Victor Hugo, em O Noventa e três, e Dickens, em Um conto de duas cidades, fornecem exemplos bastante típicos a esse respeito. Tanto no plano nacional quanto no da política externa, o humanismo é incapaz de se opor com verdadeira eficácia à "realpolitik" desumana dos poderes políticos e sociais no comando. Os conselhos humanistas resumem-se a dizer "não resista ao mal", "mantenha seu asseio individual" etc. O pacifismo puramente humanitário da Primeira Guerra Mundial, sua maneira de se proclamar em abstrato como o defensor do homem abstrato, não poderia fornecer um direcionamento para uma ação humana efetiva. Daí a grande decepção dos mais ilustres intelectuais da época, à medida que a ideologia anti-humanista a vence dia a dia em força de fascínio, em ação extensiva e intensiva.

Essa fraqueza do humanismo reside no afrouxamento de sua relação com a democracia em geral e com a democracia combatente em particular. Victor Hugo e Dickens são, sem dúvida, democratas autênticos. A crise do humanismo se manifesta entre eles na medida em que o verdadeiro caminho para a realização de seus ideais os assusta, que se perdem no labirinto de contradições criado pela Revolução Francesa, que o futuro da humanização do gênero humano não parece oferecer-lhes qualquer solução praticável. Eles aceitam os ideais jacobinos, mas rejeitam os métodos adequados para realizá-los. Mas a própria rejeição desses métodos é um sintoma do enfraquecimento do pensamento democrático, do humanismo ativo. Enquanto os adversários da democracia, sem o constrangimento de nenhum escrúpulo humanista, fazem tudo ao seu alcance para atingir seus objetivos reacionários, a ideologia do humanismo democrático, que chegou a este ponto crítico, mostra-se, por um lado, conservadora em sua forma de adesão aos ideais pré-revolucionários da filosofia iluminista, ideais de fato desviados abusivamente de seu objeto, e, por outro lado, hipercrítica, de um ceticismo autodestrutivo, quanto aos meios de realização concreta desses ideais. A negação do mal resulta em uma capitulação externa a ele, enquanto o sujeito se esforça apenas para preservar sua pureza moral individual de qualquer mácula. É somente em face do triunfo das tendências anti-humanistas e antidemocráticas no período de conquista do fascismo e durante sua dominação que o humanismo finalmente reage de uma forma mais realista. Podemos considerar 
Anatole France como o precursor dessa reação; apesar do ceticismo agudo em relação aos ideais dos jacobinos, que deveriam ser superados, ele endossa seu método ativo heroico. Esse movimento mostra que, desse ponto de vista, algo mudou entre os mais eminentes humanistas de nosso tempo. Ir além dos ideais jacobinos implica uma tomada de posição concreta e positiva em relação ao socialismo, o que de forma alguma significa que os humanistas devam a todo custo passar para o lado do socialismo, mas apenas que sua concepção do conteúdo social das ideias democráticas se tornou mais concreta, de um humanismo mais realista, que ela foi além do antigo formalismo; eles começam a se dar conta de que à violência anti-humana, à violência desencadeada pelo desvario racista, só pode se sobrepor a violência, o poder do povo finalmente desperto para a vida democrática. Vemos essa evolução ocorrendo em Romain Rolland, passando do gandhismo para a humanidade combativa; esta é a que perseguiram Thomas e Heinrich Mann. Há aí uma reação importante contra os desenvolvimentos do fim do século passado. É o início do restabelecimento da aliança entre socialismo e democracia e, por meio dela, da transição para o humanismo concreto. E a Segunda Guerra Mundial, a luta dos povos contra a "nova ordem" fascista, despertou entre os povos - em graus diversos, claro, a depender do país - reações que possibilitaram a cristalização de numerosas formas de vida democrática na nova Europa.

Chegamos aqui ao problema da nova Europa. E acreditamos que o caminho que percorremos indica claramente a resposta que deve ser dada aqui. A nova Europa só pode ser criada e mantida se conseguir extirpar as raízes do fascismo, até o plano ideológico, de forma a impossibilitar o seu regresso. Não cabe aqui dizer o quão insuficiente é tudo o que foi feito até então a este respeito, tanto em política interna quanto externa. Quando se busca tirar as lições da dominação fascista do ponto de vista da visão de mundo, vê-se que o fascismo encontrou a resistência mais forte onde havia um verdadeiro espírito democrático entre o povo, não um liberalismo formalista diluído (URSS, lugoslávia, França). Esta observação é correta, mas insuficiente. Devemos também perceber que o fascismo nunca poderia ter vencido sem essa crise da democracia e o complexo de ideias que a acompanha, o qual nós acabamos de esboçar. Essa crise tornou as massas e a elite intelectual suscetíveis ao veneno ideológico da teoria das raças, e tornou a resistência ideológica impossível, ou quase impossível. No futuro, é importante dar provas de maior perspicácia e mais energia em 
todas essas questões do que ocorreu na luta contra a ascensão do fascismo; é importante descobrir de antemão as posições de recuo da reação - como apontamos no início desta palestra - para tornar impossível qualquer restabelecimento, qualquer nova realização concreta de suas ideologias.

Para tanto, é indispensável que se desenvolva uma visão de mundo democrática; ou melhor, é indispensável que saibamos que em matéria de aristocratismo e democratismo não há neutralidade possível, que qualquer atitude filosófica implica tomar posição em relação à democracia. E, além disso, um destino como, por exemplo, o da República de Weimar mostra-nos bem a inevitável fragilidade e impotência de uma república sem republicanos, de uma democracia sem democratas.

Muitas pessoas, eu sei, acreditam ainda hoje na validade de um retorno à democracia pré-guerra, de uma restauração da velha democracia formal. Esperamos ter mostrado que esta última inevitavelmente revisitará a velha crise e assim reacenderá, no que diz respeito às massas, a força de atração da ideologia reacionária. Isso, como sempre acontece na história, em um grau ainda maior. E o breve período do pós-guerra que acabamos de viver já mostra, por vários exemplos, quão tolerante é esta forma de vida social em relação aos inimigos da democracia, enquanto opõe todo o seu poder contra aqueles que realmente desejam renová-la. Quanto a estas pessoas, elas serão frequentemente socialistas ou comunistas. Mas seria errado colocar o problema, com todas as graves consequências que isso acarreta, em termos de uma escolha a ser feita entre a cultura burguesa e o socialismo, ou entre as formas oriental e ocidental de democracia. São justamente esses falsos dilemas do pré-guerra que importa agora superar. O falso dilema do "fascismo ou bolchevismo" contribuiu extraordinariamente para o enfraquecimento ideológico das forças progressistas no período pré-guerra.

Durante a guerra, em 1941, ocorreu uma mudança importante que está intimamente relacionada com a necessária mudança de flanco de que estamos falando aqui. Se desejarmos conquistar a paz do mesmo modo como foi ganha a guerra, a política de 1941 - todo o resto permanecendo igual - deve ser continuada. Deve-se perceber que, após os efeitos devastadores do falso dilema anterior à guerra, a história universal agora oferece à democracia uma oportunidade inesperada de renascimento político, social e ideológico. A única questão é: como usar essa oportunidade?

Não é nosso papel estabelecer um programa aqui, embora estejamos 
convencidos de que nossos comentários negativos e críticos jogaram luz sobre algumas linhas gerais de tal programa. Eles trazem à tona a necessidade de uma reforma enérgica de nossa visão de mundo: categorias como as da liberdade e da igualdade, do progresso e da razão devem assumir um novo brilho, um novo alcance, e isso é possível desde que o conteúdo social da ideia democrática, adaptada às novas condições, recupere a sua plenitude e a sua potência luminosa de 1793 e 1917. E, além disso, categorias a que estamos ligados há muito tempo e que, em certos círculos, quase passaram ao posto de axiomas, como a "constituição das massas", devem se tornar obsoletas.

Do ponto de vista da visão de mundo, esta última mudança é particularmente importante; pois, o medo das massas, o desprezo pelas massas reais organizadas e conscientes, foi e continua sendo uma das vias de acesso ideológico mais importantes para o fascismo. $E$ isso, tanto no interior das próprias massas quanto entre a elite intelectual. Por último, mas certamente não menos importante, acrescentemos a isso a necessidade de superar $\mathrm{o}$ isolamento individualista de maneira positiva; devemos despertar o cidadão. Estou feliz por ter a oportunidade de falar sobre esta questão na Suíça, porque a Suíça pode se orgulhar de ter possuído, no século XIX, o maior poetacidadão do Ocidente, Gottfried Keller, e me sinto honrado de poder combater aqui sob sua bandeira. Em primeiro lugar, a sua obra, e melhor ainda, a própria história do século XIX, ensina-nos que somente aqueles para quem viver como "cidadão" voltará a ser uma forma da vida cotidiana poderão reconstruir uma Europa verdadeiramente nova. Mas ninguém pode se tornar um cidadão em virtude de uma simples resolução. O que causou o desaparecimento do cidadão na Europa Ocidental, ou sua transformação em uma caricatura abstrata, foi uma vida pública em que nenhuma possibilidade de ação contínua foi oferecida às massas, e onde a conexão entre os problemas essenciais de sua própria vida e aqueles da vida pública apenas pôde se estabelecer por vias tortas, na corrupção. Esta transformação dos seres que compõem as massas em "pessoas privadas", como ocorria nas antigas democracias formais, paralisa esses seres e dá origem a um tipo humano, uma mentalidade e uma moral contrárias a toda verdadeira democracia viva e viável. Mas, aqui, novamente, devemos ter cuidado com um falso dilema, que surge de um pensamento enrijecido em sua fetichização. Nossos contemporâneos prontamente se perguntam: é o novo homem, no caso o cidadão ressuscitado, ou são as instituições da nova democracia que devem reeducar os homens e torná-los cidadãos? Mas, na verdade, este dilema não se coloca: 
é enquanto os homens lutam pela nova democracia, enquanto eles a reconstroem, que desperta neles o espírito do cidadão; enquanto transformam sua visão de mundo, eles entram na luta pelas novas instituições da democracia.

Pode-se objetar: esta nova democracia nada mais é do que uma tentativa de restabelecer as velhas democracias diretas, enquanto Rousseau já reconheceu que os grandes estados modernos não se prestam à democracia direta. Apenas neste ponto, os liberais elogiam Rousseau além da medida. Claro, uma democracia direta como a de Atenas na Antiguidade é bastante impraticável. Mas, em seu período heroico, a grande Revolução Francesa foi toda imbuída do espírito de democracia direta e de elementos concretos emprestados dela, e a vida econômica, social e cultural da Comuna de Paris e a da União Soviética contêm uma infinidade de elementos relativos à democracia direta. $O$ próprio fato de que todas as questões concretas da vida cotidiana, como questões do domínio da vida pública, tocam as grandes massas de uma maneira direta mostra que a incorporação desses elementos na democracia proletária é consciente. A Resistência, especialmente na lugoslávia e na França, naturalmente incluía vários desses elementos. Onde quer que, após a vitória do movimento de resistência, esses elementos fossem abolidos, surgia o perigo de um concomitante enfraquecimento da defesa contra os resquícios do fascismo e de uma paralisação do ímpeto construtivo da nova democracia.

A Europa está lutando para assumir uma nova figura. Hoje, do ponto de vista formal, o que parece estar em jogo são os diferentes tipos de democracia: a questão seria saber se a democracia é uma forma simples de estado político-legal ou se deve tornar-se uma forma de vida concreta para as pessoas. Mas, lá no fundo, se esconde em realidade outro problema: o do poder. A forma democrática deve permanecer uma forma de dominação anônima das "200 famílias", como se diz na França, ou pode ser desenvolvida de modo a tornar-se uma verdadeira forma de poder dos trabalhadores? A nosso ver, tanto ideológica como politicamente, só a segunda opção e a escolha de uma visão de mundo democrática, capaz de iluminar e encorajar a sua concretização, podem fazer nascer uma nova Europa, com a garantia de impedir o retorno do fascismo e o perigo de novas guerras e nova devastação que ele implica.

Embora apenas em germe e sob o signo da contradição, a aliança de 1941 foi, desde o seu início, mais do que uma mera aliança política. Sua forma inicial foi suficiente para vencer a guerra. Mas a luta pela paz genuína deve renovar o que era a 
essência do conteúdo ideológico de 1941: a aliança entre socialismo e democracia e a constatação de que socialistas e verdadeiros democratas se encontram mais intimamente ligados por sua luta contra o inimigo comum, contra o inimigo da civilização, da cultura, do desenvolvimento, contra o fascismo, que eles não podem ser separados por suas divergências de pontos de vista, por mais fortes que sejam essas divergências nos planos social, econômico, político, cultural e universal. É essa aliança que constitui o conteúdo ideológico de 1941. E depende da própria democracia decidir se quer, através desta aliança, levar a cabo a luta pela renovação da Europa e, assim, fazer o seu próprio renascimento estrondoso, ou se quer rebaixar-se para voltar a ser o espectador impotente de uma nova Munique. O objetivo de nossa apresentação foi lançar luz, do ponto de vista de uma visão geral de mundo, sobre as condições desse dilema. 
O debate ${ }^{4}$

TERCEIRA DISCUSSÃO, 10 de setembro de 1946

Presidida por Marcel Raymond

\section{Lukács em resposta a Karl Jaspers: ${ }^{5}$}

Desejo responder brevemente ao senhor Jaspers, pois receio ver que certos preconceitos perniciosos possam comprometer o sucesso do espírito de 1941, que deveria salvar o mundo.

O senhor Jaspers disse que separava nitidamente a reflexão filosófica e a política, e quero dar duas respostas, uma do ponto de vista objetivo e outra do ponto de vista subjetivo.

Primeiramente, o ponto de vista objetivo. Constata-se na história da filosofia uma tendência geral para a universalidade. A consciência desta universalidade existiu, sendo mais ou menos clara a depender do autor, de acordo com sua consciência da interdependência dos diversos âmbitos. No início do século XIX, durante a época do socialismo utópico, criou-se uma sociologia separada e uma economia separada para o maior malogro de ambas. Meu pensamento não é um sistema monocausal. Não se deve separar política e filosofia; elas são inseparáveis.

O lado subjetivo é que, no mundo moderno, o cidadão morreu para permitir a sobrevivência unicamente de um indivíduo privado e isolado. $O$ homem se viu partido em dois. É inevitável que um homem partido ao meio esteja impotente. Mas isso é apenas o resultado de certos desenvolvimentos sociais que podem ser superados. Por exemplo, na lugoslávia e na Resistência francesa, no esforço empreendido contra o fascismo, o cidadão voltou à vida e tornou-se membro de uma comunidade ativa e, desse modo, ele foi mais ativo contra o fascismo. O senhor Jaspers vai achar que eu falo mais uma vez de política, mas ao mesmo tempo estou falando sobre espírito, sobre cultura e tudo mais. Muitas coisas são feitas para superar essa impotência que

\footnotetext{
${ }^{4}$ Além das conferências, a programação do evento contou com cinco sessões de debate. O filósofo húngaro interveio nas três últimas, respondendo a alguns dos questionamentos que lhe foram feitos pelos presentes, cujo conteúdo buscamos resumir nas notas de rodapé. As intervenções de Lukács foram feitas em alemão e, posteriormente, resumidas em francês. Nos anais do evento, portanto, temos acesso somente esses resumos, que foram aqui vertidos ao português [N.T.].

${ }^{5}$ Pouco antes, nesta mesma discussão, Jaspers dirigira contra Lukács as acusações de confundir política e espírito, desviando-se do tema próprio do encontro, e conceber o desenvolvimento histórico como uma linha clara e unívoca, dentro de um sistema monoexplicativo e monocausal. Como Lukács, ele se expressa em alemão e temos acesso somente ao resumo traduzido de sua intervenção [N.T.].
} 
o senhor Jaspers reputa como essencial. Ela não é essencial. Ela é acidental e pode ser derrotada. A política deixará de ser um destino avassalador.

Falei em terminologia moderna e espero ter levado ao menos alguns de nós a refletir sobre si mesmos e a tomar consciência desse novo aspecto do problema.

\section{QUARTA DISCUSSÃO, 12 de setembro de 1946 Presidida por Victor Martin}

\section{Lukács em resposta a Jean Starobinski: ${ }^{6}$}

Fico feliz em responder ao senhor Starobinski, que me deu a oportunidade de esclarecer minhas ideias sobre muitos pontos.

O mundo, disse o senhor Starobinski, tende à totalidade e se encontra diante de um problema total. Em efeito, progressivamente, a civilização eliminou o mundo bárbaro, difuso em torno de civilizações restritas. Mas o senhor Starobinski negligenciou a causa disso, que é em suma simples e não espiritual. Se o mundo evoluiu desta maneira, é porque o capitalismo, atualmente, penetrou no mundo inteiro, e foi a penetração universal do capitalismo que suprimiu a configuração de cultura limitada, da qual falava o senhor Starobinski.

Por outro lado, no interior das comunidades, a contradição permanece mais atuante do que nunca. Em efeito, existem sistemas econômicos parciais que buscam a hegemonia e comprometem o equilíbrio do todo. É daí que vem a violência do fascismo e é assim que o fascismo se constitui como uma caricatura da totalidade.

Gostaria de responder ao senhor de Salis ${ }^{7}$ a respeito de vários pontos da sua conferência. Em primeiro lugar, o senhor de Salis disse, afirmando-o, que qualquer governo que aja pela força pode ser equiparado a qualquer outro, e que se deveria aplicar a todos a mesma categoria. Esta é uma simplificação equivocada. É necessário, em verdade, considerar o objetivo a que se propõem esses governos, e ademais, 0 critério adotado pelo senhor de Salis não é claro nem válido. O senhor de Salis disse que a Rússia talvez seja atualmente contrarrevolucionária. Com essa sugestão, ele nos faz voltar a um estado lamentável, anterior à guerra, que deixou a Europa indefesa

\footnotetext{
${ }^{6}$ Remetendo à relação entre cidadão e estado, Starobinski perguntou a Lukács se acreditava que a noção de cidadão deveria implicar uma religião civil, como concebera Rousseau, e se tal religião não implicaria uma restrição à liberdade [N.T.].

7 Jean-Rodolphe de Salis proferira sua conferência no dia 5 de setembro [N.T.].
} 
contra a catástrofe.

As ideias do senhor de Salis a respeito das duas Europas parecem-me perigosas, porque nos levam a enfatizar o contraste entre as duas, correndo o risco de nos levar de volta ao estado pré-guerra como se não tivéssemos aprendido nada, ou esquecido tudo, como os emigrantes da Revolução Francesa. Não se deve esquecer a inflexão definitiva ocorrida em 1941, quando Roosevelt e Stalin forjaram conjuntamente a grande ideia segundo a qual, diante da ameaça fascista, era necessário que todas as forças democráticas se aliassem, apesar de suas diferenças. Tudo depende do destino que terá essa ideia em tempos de paz.

Há, evidentemente, grandes diferenças entre os diferentes tipos de democracia, mas há também, do meu modo de ver, grandes diferenças entre a democracia francesa e a democracia inglesa.

Por outro lado, do ponto de vista espiritual, para não nos restringirmos à política, pode-se dizer que a cultura filosófica da Europa do século XVIII, notadamente a francesa, se encontra particularmente viva hoje na Rússia.

Para responder ao senhor Starobinski quanto à noção de cidadão, não penso que uma personalidade inteira possa se identificar com o papel e a função de cidadão. Não. Mas é indispensável, caso se queira ter personalidades completas, que sejam também cidadãos, senão têm-se seres mutilados e empobrecidos; tal era o homem do século XIX, muito diminuído em comparação com o homem antigo ou com o cidadão recriado pela Revolução Francesa.

Da mesma forma, não se trata absolutamente de instaurar um novo fetichismo de estado. Pelo contrário, pode-se constatar que na antiguidade não havia tal fetichismo de estado. Este não surgiu até o momento em que o estado se separa da sociedade e quando, em consequência dessa desintegração, dessa ruptura da unidade, o próprio homem se despedaça. A noção de cidadão, ao contrário, impede isso, uma vez que não há mais conflito absoluto entre o interesse individual e o da comunidade, o estado, pouco a pouco, tende a perder sua importância, tende a, progressivamente, desaparecer, por assim dizer, no funcionamento do todo. É necessário tender, consequentemente, a diminuir a importância do estado do ponto de vista próprio ao socialismo, ao marxismo. 


\section{Lukács em resposta a Karl Jaspers: ${ }^{8}$}

Primeiramente, o professor Jaspers não desenvolveu [em seu comentário] o ponto de vista filosófico em si, mas os traços fundamentais de sua própria filosofia, que é a filosofia existencialista.

No meu modo de ver, esta filosofia é uma construção engenhosa e cheia de espírito, mas é apenas um reflexo do homem privado e cindido de que falei durante minha conferência.

Por outro lado, a ideia de totalidade não é invenção de um filósofo, mas se impõe por si mesma na vida cotidiana; quando um cidadão não paga seu aluguel, nas consequências daí advindas, a totalidade lhe é imposta com toda a sua força, e o pensamento marxista apenas eleva a um nível superior de pensamento essa totalidade que somos forçados a viver na vida cotidiana, quer queira, quer não, tenhamos consciência ou não, tiremos consequências disso ou não. Eu acredito ter extraído essas consequências.

\section{QUINTA DISCUSSÃO, 14 de setembro de 1946 Presidida por Ernest Ansermet ${ }^{9}$}

Tentarei responder a todas as perguntas que me foram feitas. Muito foi dito sem responder ao propósito dessas discussões, um exemplo é a conferência de Bernanos. ${ }^{10}$ Trata-se aqui de construir uma nova Europa, e Bernanos falou como ninguém poderia falar a propósito dos piores momentos de Munique. Chegou o momento de apanhar o caráter decisivo da situação europeia. Nós estamos falando aqui sobre visão de mundo, mas não sem propósito. É necessário que esta visão de mundo seja eficaz para salvar o mundo.

Os senhores Goldman e Merleau-Ponty ${ }^{11}$ sublinharam que a situação atual não é mais a de 1941. Em 1941, a aliança tinha dois aspectos. Por um lado, ela se afirmava contra o fascismo e, por outro, representava um antagonismo; ela era o resultado de um antagonismo entre os imperialismos da Alemanha, Japão e Itália, de um lado, e o

\footnotetext{
${ }^{8}$ Pronunciando-se logo em seguida a Lukács, Jaspers interpelou-o longamente sobre a categoria da totalidade [N.T.].

9 Última intervenção de Lukács durante o encontro. A tradução consecutiva desta intervenção, conforme indicado nos anais, foi feita por Jeanne Hersch [N.T.].

${ }^{10}$ Georges Bernanos proferira sua conferência em 12 de setembro [N.T.].

${ }^{11}$ Questões levantadas ainda durante a quarta discussão, do dia 12 de setembro [N.T.].
} 
imperialismo ocidental, de outro. Agora se trata apenas de evitar o retorno do fascismo. Mas, por outro lado, o imperialismo, que estabelece para si novos objetivos, confunde a situação e se vale de resquícios do fascismo. É necessário restabelecer a aliança de 1941 e impedir qualquer cumplicidade com o fascismo. Hoje, é esta a questão. Não há dúvida de que o socialismo é a força com maior capacidade de extirpar - fascismo, mas sejamos realistas. Como é impossível nesse momento realizar o socialismo na Europa, esta seria uma ideia desastrosa. Portanto, se dizemos que é necessário manter a aliança de 1941, isso significa que queremos mantê-la entre socialistas e não socialistas; pouco importa as diferenças que subsistam no interior da aliança, desde que resistamos ao perigo maior: o fascismo.

Esses senhores perguntaram qual era o significado da palavra democracia. A democracia formal remete em suma, no mais das vezes, ao imperialismo das duzentas famílias, para usar a expressão francesa. Trata-se de tornar isso impossível. Não quero falar de política, mas seria necessário que cada país examinasse por quais vias poderia eliminar esse imperialismo das duzentas famílias. Como a democracia formal se transforma facilmente em fascismo, há o risco de que as consequências sejam catastróficas. É perigosa a confiança que muitos continuam a ter no formalismo democrático, opondo-se à URSS; e esse espírito é uma nova catástrofe.

O estado de espírito da impotência, por outro lado, expresso por muitos, é bastante perigoso. Tal como foi formulado pelo senhor Jaspers, corre o risco de não apenas levar à constatação da impotência dos intelectuais, mas também, por tabela, tornar as massas impotentes. Não farei a crítica da filosofia existencialista, mas uma consideração sobre uma atitude decorrente da situação. O senhor Jaspers falou sobre ordem mundial e a dominação mundial, e ele preconiza, corretamente, a ordem mundial. Está correto, e eu concordo, mas não se deve falar como se ela já existisse, porque de modo algum existe. Não devemos nos iludir. $O$ senhor Jaspers não é o único a assumir essa postura; ela é generalizada entre os intelectuais europeus há cerca de um século. A interioridade é protegida a força, e basta reler Morte em Veneza para ver a crítica que Thomas Mann lhe faz. Toda essa postura de resignação e impotência provém, na realidade, simplesmente do fato de que o homem foi inteiramente cindido desde a morte do cidadão. Gottfried Keller, com sua compreensão de cidadão, descreve de todas as maneiras possíveis a falência dos homens completamente "privados" e, portanto, impotentes. 
Guéhenno disse ${ }^{12}$ que a França foi obrigada a se politizar como resultado da Resistência; mas, hoje, a Resistência deve ser mais política do que nunca, pois as piores traições ainda estão por vir. Ele disse ainda que a Resistência foi formada por uma aliança de opiniões diversas contra o inimigo comum. Encontro-me em uma situação paradoxal; cada palavra que digo parte do marxismo, que tende à criação do socialismo, mas acredito que o objetivo imediato hoje não é estabelecer o socialismo; é produzir uma reação defensiva contra o fascismo.

O senhor Merleau-Ponty falou da possível destruição dos dois adversários; ${ }^{13}$ é isso que dá todo o peso às minhas palavras. O perigo é grande demais, a casa está em chamas, antes de qualquer outra coisa devemos buscar água.

\section{Como citar:}

LUKÁCS, György. O espírito europeu (1946). Tradução de Carolina Peters. Verinotio, Rio das Ostras, v. 27, n. 1, pp. 9-39, jan./jun 2021.

12 Ainda durante a terceira sessão de debates, no dia 10 de setembro, Guéhenno, sem deixar de demarcar sua divergência com Lukács, havia dito, em resposta a Rousseaux, que defendera contra o húngaro um caráter antes místico que político da Resistência francesa à invasão nazista, que se a traição fora política, a resistência a ela só poderia ser igualmente política [N.T.].

${ }^{13} \mathrm{Na}$ realidade, é Goldman (provavelmente Lucien Goldmann), que faz sua intervenção imediatamente após Merleau-Ponty, quem levanta a questão de que uma aliança malsucedida entre as democracias ocidentais e os países socialistas resultaria em uma nova guerra catastrófica [N.T.]. 